\title{
Dynamic capabilities to match multiple product generations and market rhythm
}

\author{
Scott G. Dacko \\ Warwick Business School, The University of Warwick, Coventry, UK \\ Ben S. Liu \\ Quinnipiac University, Hamden, Connecticut, USA \\ D. Sudharshan \\ Gatton College of Business and Economics, University of Kentucky, Lexington, \\ Kentucky, USA, and \\ Olivier Furrer \\ Nijmegen School of Management, Radboud University Nijmegen, Nijmegen, \\ The Netherlands
}

\begin{abstract}
Purpose - The purpose of this paper is to provide greater insights to managers seeking to time properly the launches of innovative new products (NPs) across multiple generations. This paper aims to address the rhythm matching problem by developing a typology and a conceptual framework of the interaction between a firm's technological readiness to launch NPs and a market's receptivity in influencing a firm's long-term performance.

Design/methodology/approach - Based on the new product development (NPD) and diffusion of innovation literatures, the paper develops a model explicitly to address the rhythm matching problem by highlighting the interaction between a firm's technological readiness to launch new products and a market's receptivity in influencing a firm's long-term performance. The logic of this model may be described as follows: long-term performance is a function of matching: products to customer needs, marketing mix dynamics to customer segments and buying behavior dynamics, and logistics, supply chain management, and inventory to market dynamics and financial efficiency; uncertainty in: knowledge of needs, market segments and their dynamics, and market dynamics is all a function of time, as is financial efficiency. Therefore, a firm's long-term performance is a function of these matches over time.

Findings - Deriving from the proposed model and typology, it was found that in independent rhythm windows, the management focus is on a single generation and each successive generation can be planned independently. In market-imposed windows, firms aim at adapting their own NP readiness rhythm to the market receptivity rhythm. In firm-imposed windows, firms have the initiative to drive the market receptivity rhythm. In dynamically resultant windows, everything is more complicated because firms' NP readiness rhythm and market receptivity rhythm influence each other.

Originality/value - The model and typology developed in this paper are a breakthrough result of synthesizing various traditions of NPD and diffusion of innovation research. It is believed that the paper provides a rich conceptual framework drawing together extant research on the development and introduction of new products. The framework is intended both to explicitly inform managers of the importance of rhythm matching as well as to the factors that influence such matching. It is also intended to provide a lens with which further research can be directed to increase the efficiency and effectiveness of resource utilization in NPD and the long-term success of the firms.
\end{abstract}

Keywords Market entry, Technology led strategy, New products

Paper type Research paper 
We take a multigeneration approach to product development. That approach helps us to keep the technology risk low for the first generation while preparing us for the changing future. Right from the beginning, we set goals for succeeding generations (Lewis S. Edelheit, ex-Vice President, General Electric Company).

\section{Introduction}

The success of a new product introduction depends on its timing. Too late an entry is likely to lead to significant loss of opportunity. Entered too early, a new product may not take off as customers, channel members, and other required partners might not be receptive enough. Thus finding the right window of entry (or in Abell's (1978) words "the strategic window of opportunity") is of critical importance. This implies that a firm should be ready to exploit the entry window in a market.

Furthermore, the long-term performance of a firm depends not only on the success of a new product introduction timing, but also, and more importantly, on the successful introduction of successive generations of new products. In many markets today, as suggested by the quote from Lewis S. Edelheit of General Electrics shown earlier, success depends on planning for several generations and associative products over time. Gillette's innovation timeline in the last 100 years shown in Table I provides a vivid picture of market rhythm in the shaving equipment industry. As it can be seen in Table I, Gillette tried to impose a rhythm on the shaving equipment market by regularly introducing breakthrough innovations followed by a series of incremental innovations. By creating such a rhythm and by planning and managing new product introductions across successive generations, Gillette was able to sustain its market performance.

In a recent article, Hauser et al. (2006) propose an agenda for research on diffusion of innovation. Among those prior works reviewed, Mahajan and Muller (1996) examining the timing, diffusion, and substitution of successive generation of the IBM mainframe emphasizes the importance of carefully managing the rhythm of new product introduction timing. They note, "determination of optimal introduction time is especially critical for high-technology products, where the introduction of each success generation of a product requires the firm to explicitly consider its impact on the demand for the preceding generation and vice versa" (Mahajan and Muller, 1996, pp. 109-10).

Firms seeking to establish appropriate rhythms for market entry timing must consider both the industry and market contexts. In some industries, it may be that the firm's rhythm drives the market rhythm while in other industries the market rhythm may dominate. For example, the development of next-generation computer software by software firms, such as Microsoft, ultimately leads customers to update their software products over time. Vahaniitty (2003) identifies that small companies in the software product business risk rework and market failure due to shortcomings in integrating a strategic perspective into management of product development. To overcome such a problem, he proposes that improvement should begin with helping the key persons maintain the "big picture" that includes the rhythm of the new product development in the industry. On the other hand, the development of new apparel items by fashion firms clearly has a seasonal rhythm (Miller et al., 1993) not to be missed by any firm in the industry. Still other industries are sufficiently complex that both firm rhythms and market rhythms interact to drive the pace of development and new product acceptance. 
1901 King C. Gillette invents the safety razor with disposable blades

1903 Gillette manufactures the first safety razor

1904 Gillette receives the first US patent on the safety razor

1915 Gillette introduces the first women's razor: Milady Décolletée

1932 Gillette introduces the Gillette Blue Blade

1938 Gillette introduces the Gillette Thin Blade

1946 Gillette introduces the first blade dispenser the Gillette Blue Blade Dispenser

1957 Gillette introduces an adjustable razor with three settings light, medium and heavy designed for men who want to match the angle of their blades with the toughness of their beards

1960 Gillette applies a silicone coating to the blade edge to improve quality, safety and comfort of the shave. The new coated blade is called the Super Blue Blade

1963 Gillette introduces a coated stainless steel blade Gillette Super Stainless

1969 Gillette introduces platinum chromium coating of blades, designed to enhance corrosion resistance

1971 Gillette introduces Trac II with two blades

1975 Gillette introduces Daisy, the first disposable razor for women

1976 Gillette introduces Good News!, the first twin blade disposable razor for men

1977 Gillette introduces the Atra shaving system

1985 Gillette introduces the first razor with a lubricating strip Atra Plus

1986 Gillette introduces the first disposable razor with a lubricating strip Good News! Plus

1989 Gillette introduces Sensor with spring-mounted blades

1992 Gillette introduces Sensor for Women

1994 Gillette introduces SensorExcel with two blades and five microfins

1996 Gillette introduces SensorExcel for Women

1998 Gillette introduces MACH3 with three blades

2000 Gillette introduces Gillette for Women Venus

2001 Gillette introduces MACH3Turbo with three blades and ten microfins

2004 Gillette introduces M3Power with three blades and power

2006 Gillette introduces Fusion Manual with five blades and a trimmer

2006 Gillette introduces Fusion Power with five blades, a trimmer, and power

2007 Gillette introduces Fusion Power Stealth, with a sleek new design

Source: www.tycoon.com/content/custom/tycoon/Gillette/UltimateShaveGuide.pdf

Table I.

Timeline of Gillette's shaving firsts

For example, the development of computer memory chips (e.g., DRAM) by large integrated circuit manufacturers is based on both internally-driven and planned cycles as well as the market's needs for memory chips with greater capabilities. At the same time, some firms and markets either do not have a particular rhythm or have rhythms that are so long as to not impact firm or market growth (e.g., metal staple manufacturers for the standard desk stapler market). For those product-markets where either the market exhibits a rhythm in new product receptivity, the product manufacturers exhibit rhythms in new product launches, or where both rhythms are present, it can be argued that superior long-term performance by any given firm is likely to be a function of the interaction of the firm's new product launch and market rhythms.

It is the primary purpose of this paper to address the rhythm problem by developing a conceptual framework of the interaction between a firm's technological readiness to launch new products and a market's receptivity in influencing a firm's long-term performance. The logic of this paper may be described as follows: long-term performance is a function of matching products to customer needs, marketing mix 
dynamics to customer segments and buying behavior dynamics, and logistics, supply chain management, and inventory to market dynamics and financial efficiency (a firm's cash utilization and capital over time). Uncertainty in knowledge of needs, market segments and their dynamics, and market dynamics is all a function of time, as is financial efficiency. Therefore, a firm's long-term performance is a function of these matches over time. We propose, in this paper, that these matches can be viewed as the match of firm readiness and market receptivity. Firm readiness is a function of absorptive capacity and resource utilization whereas market receptivity is a function of time and the presence and availability of complementary products and services. Therefore, a firm's long-term performance is a function of the firm readiness-market receptivity match. Our argument is that over several generations, firm's long-term performance can be improved by anticipating the market receptivity rhythm and by creating and matching an inside rhythm, rather than striving to match each individual generation's rhythm.

\section{Firm's new product readiness and market receptivity rhythms \\ Firms' new product readiness rhythm}

Firms that compete through the internal development of new products for introduction into markets of increasing technological sophistication are continually engaged in a process of readying themselves to launch new products. Much in the new product development literature addresses the topic of firm readiness either directly or indirectly (see Scherer, 1967; Stalk, 1988; Thomas, 1993; Holmes and Srivastava, 1999; Conte et al., 2004). We define readiness as the overall level of preparedness of the firm to introduce a new product. When a firm has a relatively consistent cycle in developing and launching subsequent generations of its products, the firm can be said to have a rhythm in its new product development efforts. Each firm developing new products incorporating new technologies participates in an ongoing series of development cycles, each beginning with conception based on need and ending with production and launch (Griffin, 1997).

Firms in different industries have different dominant cycles. Griffin (1997) provides numerous examples of firms in different industries having differing product development cycle times. Examples include 14 months from conception to production for a personal computer to 36 months for a new car to 72 months for a new hybrid corn. US car manufacturer cycle times in the mid-1980s averaged 60.4 months (Womack et al. 1985), while the same manufacturers averaged 61.9 months in the late 1980s and early 1990s (Manton and Tennant, 2000). Even when firms in a given industry strive to reduce their overall cycle times, each industry tends to have dominant development time ranges for their new product development cycles (Milson et al., 1992).

\section{Product market receptivity rhythm}

A product market rhythm is the regular recurrence of favorable marketplace receptivity for new-generation products. The time-dependent consumption cycle of products incorporating a particular technology and the typical budget cycle of the firms or individuals using the new technologies may influence the purchase rate (and hence market receptivity) for new products. For example, the widely varying consumption and budget cycles for various state-of-the-art medical apparatus in hospitals illustrates how equipment purchase rates for such equipment, including the 
timing of planned replacements of prior generation technologies, may be dramatically affected. Seasons, industrial customers' product development and production cycles, and swings in customer spending all may influence product market rhythm (Eisenhardt and Brown, 1998). Eisenhardt and Brown (1998) also cite the seasonality of demand for cold-beverages, with its peak during the mid-summer, as an example of a product with a strong rhythm. They also cite retail stores such as Wal-Mart and Target as having regular, seasonal shelf-planning cycles for a variety of household goods purchases (e.g., school supplies and small house wares). The receptivity for new products often evolves in parallel with such natural rhythms.

\section{Multiple generations and long-term performance}

In reviewing the marketing and strategy literature examining the interactions of firm and market rhythms affecting a firm's new product development efforts we find that extant research examines many aspects of the important rhythms affecting the technologically innovative firm. However, with few exceptions, papers in this area restrict themselves to examining just one or a few aspects of rhythm and do not seem to connect their work to a more elaborate rhythm framework, even though multiple generation rhythms are a market phenomenon (Arslan et al., 2007; Edelheit, 2004; Mahajan and Muller, 1996). For example, Thomas (1985) clearly examines the importance of timing but in a limited context of the introduction of a single new product. Kalish and Lilien (1986) discuss the negative consequences of mistiming a market entry in terms of the negative word-of-mouth that is generated, yet the authors again focus on the introduction of a single technology-based new product.

Research discussing the interaction of multiple firm and market rhythms in new product development is exemplified by Eisenhardt and Brown (1998) and Brown and Eisenhardt (1998). In their research, the authors adopt a multiple generation view and discuss a general competitive strategy of firms scheduling change at predictable time intervals for better performance in unpredictable markets. Eisenhardt and Brown recommend that product launches of firms should be "calendar driven" rather than "customer or technology driven." Although advocating a rigid periodic schedule, the authors also acknowledge a need to consider the cycles of suppliers and customers for the right "time pace," or optimal interval for launch (Eisenhardt and Brown, 1998, p. 7; Laitner, 1998).

Another exemplar of the multiple generation approach is research by Norton and Bass (1987), where they propose a diffusion theory model for successive generations of high technology products. In the Norton and Bass model, which is based on the Bass (1969) diffusion model, variables representing the incremental potential served by each successive generation of technology are incorporated and later calibrated for a particular product market. According to the authors, observations from the first one or two generations (of, say, DRAM technology) may be sufficient to estimate future incremental potentials served by successive generations of technology. Still, much remains to be known about just what exactly drives the rhythms of technology advancement as well as what determines long-term performance for a particular firm. For example, research by Kim et al. (2000) on wireless telecommunications services has found that generational dynamics are also significantly influenced by the sales of other related product categories, suggesting that the future success of multiple generations of products must take into account related product category sales as well. 
Based on the research pertinent to the interaction of firm and market rhythms, there is clearly a need to develop a formal and comprehensive model that links the match between firm and market rhythms to long-term performance for multiple generations of technology-based new products and identifies and discusses the many factors that influence both firm and market rhythms. This next section addresses these aims by presenting a general conceptualization of these internal and external rhythmic influences. (In this paper, internal and firm rhythms are used interchangeably, as are external and market rhythms.) The objective of the parsimonious model is to better examine how the rhythms impact upon the firm's technology advancement efforts in product development which, in turn, can influence a firm's long-term performance.

\section{Trade-off between speed of entry and performance}

The marketing literature suggests that there is a tradeoff between speed of entry and market performance for any given generation of a new product (Wong, 2003; Bayus, 1997; Crawford, 1992; Stalk and Hout, 1990;). Much attention is found in the marketing strategy literature on the growing imperative for firms to achieve faster cycle times in their new product development efforts and their need to respond more quickly to changing market needs (Christensen, 1997a; Cooper and Kleinschmidt, 1994; Stalk, 1988, Stalk and Hout, 1990). Studies emphasizing the importance of first-mover or pioneering advantages (e.g., Carpenter and Nakamoto, 1989; Lieberman and Montgomery, 1988; see Kerin et al. (1992) for a review) in competitive strategy further reinforce the notion that firms with rapid new product development capabilities are in better competitive positions than firms with slower product development capabilities. Carpenter and Nakamoto (1989) argue that such firms can obtain consumer-based advantages including influencing how consumers evaluate attributes in the product category and perhaps "locking in" consumers in categories that have high switching costs. Lieberman and Montgomery (1988) argue that such firms can also obtain producer-based advantages including technological leadership (e.g., setting the standard for a product) and preemption of scarce assets including investments in plant and equipment or other resources.

It is also recognized by many academics and marketing managers, however, that faster new product development is not always better, nor is earlier market entry always preferable (Wong, 2003; Bayus, 1997; Bayus et al., 1997; Cohen et al., 1996; Crawford, 1992; Gilbert, 1993; Kerin et al., 1992; Morgan et al., 2001; Schnaars, 1986, 1994; Shankar et al., 1999). Gilbert (1993) notes, for example, advantages of delaying introductions of certain technology-based new products including greater knowledge of how technological or regulatory issues will be resolved (as with VHS and Beta technologies) and free-riding on the investments of earlier entrants (as with the earlier entrant's development of infrastructure for cable television). Kerin et al. (1992) further argue that the extent of a first-mover's positional advantage, ranging from cost advantages to differentiation advantages, will invariably be moderated by a variety of technological, economic, behavioral, and pre-emption-based factors. The authors argue, for example, that the presence of technological discontinuities may act to favor fast followers more than first movers since a first-movers' investments in and experience with older technologies can hinder its preparedness to adopt quickly major new technologies. Schnaars (1994) also show in a succession of cases, such as 
Microsoft, American Express, and Pepsi Co, that late-movers with deep pockets and strong marketing capabilities are able surpass first-movers by:

- offering lower prices;

- selling superior products; and

- using their power to overwhelm weaker pioneers.

Shankar et al. (1999) also show that firms entering during the growth stage of the product life cycle reach their asymptotic sales levels faster than pioneers or mature-stage entrants, are not hurt by competitor diffusion, and enjoy a higher response to perceived product quality than pioneers and mature-stage entrants. This suggests the importance of entering the market at the right time.

Types of mismatches and their performance implications

The literature has identified six different types of mismatch between market receptivity rhythm and firm's new product (NP) readiness rhythm. They are graphically represented in Figure 1, where the market receptivity rhythm is shown as a dashed-line curve and firm readiness rhythm is shown as a solid-line curve. A firm may develop and launch a new product too early when the market is not yet receptive (panel 1) or too late (panel 2), it may start new product development too early and have to slow it down to launch the product at the right time (panel 3) or start too late and have to speed up the process (panel 4), and finally it may develop and launch a product that does not have the performance level desired by the market (panel 5) or develop and launch a product that is too sophisticated for current market needs (panel 6). Later in this paper, propositions will be developed and discussed that will include the types of market mismatches proposed here.

Market receptivity rhythm is shown as a dashed-line curve and firm readiness rhythm is shown as a solid-line curve

1. Too early

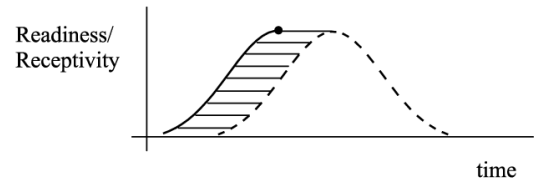

3. Too slow

Readiness/ Receptivity

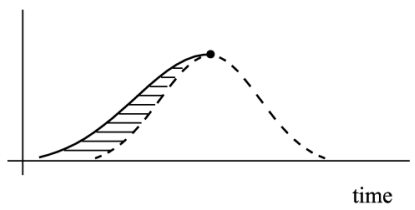

5. Too little

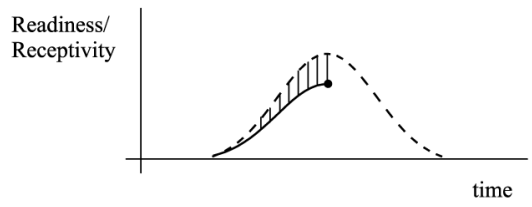

2. Too late

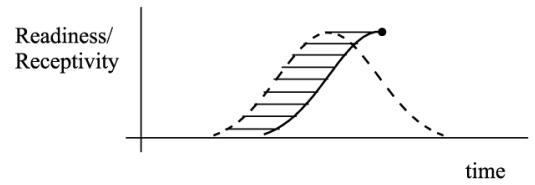

4. Too fast

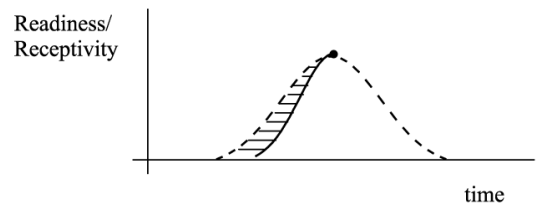

6. Too much

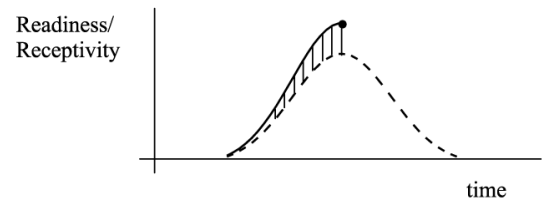

Figure 1. Matching firm new product readiness rhythm and market receptivity rhythm 
The effects on performance of being too early or too late have been extensively described in the literature on first/later entrant advantages and disadvantages. Several empirical studies report that market pioneers have an advantage (e.g., see the review by Kalyanaram et al. (1995)), with the implication being that firms should always speed new products to market. At the same time, however, other empirical studies find that later entrants have an advantage (Wong, 2003; see Kerin et al. (1992) and Schnaars (1994) for a critical review of the stream of research). In these studies, new product launch timing is based on the timing of competitors, however timing should also be based on customers' timing - i.e. market receptivity rhythm.

The importance of product performance has also been emphasized in the literature. Several empirical studies have shown that a new product's success depends critically on its performance and its value to customers. If it is too sophisticated, a new product will not appeal to mass market; too little performance, the new product will not take off. For example, Zirger and Maidique (1990) examined 330 new products in electronics industry and showed that performance and timing significantly affected product profitability. Cooper and Kleinschmidt (1987) demonstrated that product superiority in terms of unique features, innovativeness, and performance is a key factor that differentiates new product winners from losers.

The trade-offs between speed-to-market and new product performance have also been investigated (Wong, 2003; Bayus, 1997; Bayus et al., 1997; Cohen et al., 1996). Significant improvements in product performance have the potential to capture a larger market share from competing products, but they may take too long to accomplish and, consequently, firm will miss the window of opportunity (Cohen $e$ al., 1996). Bayus (1997) developed an analytical model to identify the optimal speed-to-market and new product performance decisions and the associated market, demand, and cost conditions. Based on a detailed case study of the initial competitors in the personal digital assistant industry, Bayus et al. (1997) show, in particular, that Apple's Newton was "too little, too early."

In contrast to the above research, mismatches among market receptivity rhythm, firm new product $(\mathrm{NP})$ readiness rhythm, and the consequences of new product development cycle time have not been fully examined. Following the pioneering work by George Stalk (Stalk, 1988; Stalk and Hout, 1990), time has become a critical objective for most companies. To support the belief that speeding new products to market is necessary in today's environment, spectacular success stories of companies that have dramatically reduced their development times have been reported (Griffin, 1993). This led to the development of a whole literature on the approaches and techniques that can be used to accelerate the new product development process (e.g., Gaynor, 1993; Patterson, 1993; Smith and Reinertsen, 1998; Wheelwright and Clark, 1992). However, most of this research seems to have forgotten the early work on the time-cost trade-off (e.g., Foster, 1982, 1986; Graves, 1989; Scherer, 1966). For example, Foster (1982, 1986), discussing the time-cost trade-off, notes that the rational manager wishes to minimize the sum of two costs:

(1) the opportunity cost of entering a market too late; and

(2) the project development cost.

Graves (1989) reviewing this literature identifies that the curve is strictly convex implying that there is an optimal timing. 
Understanding rationale for mismatch-performance link

Two theoretical reasons seem to lie behind firms' time-cost trade-offs: firms' absorptive capacity (Watanabe and Kwintiana, 2003; Cohen and Levinthal, 1990, 1994) and uncertainty about consumers' needs and preferences (More, 1984).

Cohen and Levinthal (1990) define absorptive capacity as the ability to recognize the value of new information, assimilate it, and apply it to commercial ends. They argue that a firm's absorptive capacity is a function of prior related knowledge. A firm's absorptive capacity represents the limit of its ability to speed up its new product development time. A limit to a firm's absorptive capacity is supported by the fact that development costs will increase as project duration is compressed because of information loss with acceleration (Graves, 1989) and diminishing returns (Brooks, 1975). Graves (1989, p. 2) described the loss of information resulting from project duration compression as follows:

Since R\&D is a heuristic process involving great uncertainties, each step is based upon information gained in previous steps. Compression of development time requires greater overlap of requisite steps in the development process, which in turn causes each task to be undertaken without the full information which might have been gained from other steps had they been accomplished in sequence. With more and more compression, each task is begun with less and less information. This leads to mistakes and rework.

Conventional diminishing returns are observed as more and more technical people are assigned to the same task. Brooks (1975) has described this phenomenon as the mythical man-month, observing that each additional person assigned to a project contributes incrementally less than the previous one since he or she must spend time being educated by experienced team members, thus reducing overall productivity.

A firm's absorptive capacity represents a limit to its capability to speed up its new product development cycle time. A firm with a small absorptive capacity will be penalized by large development costs if it tries to speed its new products to the market.

The second element in favor of developing a firm's readiness at the same pace than market receptivity is related to the uncertainty about the needs and preferences of the market. Empirical studies have shown that one of the most important factors influencing new product successes is the identification and understanding of customers' needs and market potential (e.g., Zirger and Maidique, 1990). So, if a firm starts developing a new product before a market develops a need for such a product, it will have to commit a great deal of investment to identifying consumer needs and educating consumers (Schnaars, 1986). More (1984), examining the timing of market research expenditure in 112 new industrial product situations, found that the total spending of the companies was consistent with the levels of the risk and uncertainty involved: that is, managers did more research in situations involving new customers and uncertain adoption processes.

Moreover, starting the development process too early will also generate costs of modifying the new product according to uncertain customer needs and preferences, which may change over time according to new information and new technology available. Krishman (2001) cites, for example, the case where an automotive company commits itself to developing a new three-door minivan making it unfeasible to introduce a new four-door van, yet emerging consumer demands can only be met with a four-door van. 
Organizational routines (Nelson and Winter, 1982) and core rigidities (Leonard-Barton, 1992) create resistance to changes in a firm's NP readiness rhythm from one generation of new product to the next. External shocks (one time only stochastic events) are often blamed for a mismatch, leading a firm to implement the wrong (single generation) solution to the problem. If the mismatch is a consequence of organizational routines, then the problem is better solved by a change in organization competencies and capabilities. Teece et al. (1997) define these competencies and capabilities that allow a firm to reconfigure internal and external competences and resources to address the problems related to routines and core rigidities, dynamic capabilities.

If a mismatch occurs at a given generation and it is not worked on, a self-reinforcing rhythm due to the routines of the firm, leading to disaster, is likely to occur. A new product introduction that is too early or too late will generate a lower profit and thus a lower availability of resources to be invested in changing a firm's NP readiness rhythm. This, too, will lead to a downward spiral. Too much mis-directed change with limited resources can occur when a firm has an internally product focused culture rather than market focused culture. In such a situation, if such a firm does not change its culture, it would be less likely to change its readiness rhythm. Too little change can also result from market information gathered from actual customers that are not sophisticated enough (Christensen, 1997b) rather than potential lead user customers (e.g., von Hipple et al., 1999). Better market sensing capabilities need then to be developed by a firm to be able to catch the market receptivity rhythm. Too fast a rhythm is more likely to occur when a firm is seeking first-mover advantage at any cost (e.g., Lieberman and Montgomery, 1988), and too slow a rhythm is more likely to occur when a firm is pursuing an imitator strategy (Schnaars, 1994). In both cases, strategic intent needs to be reassessed to match the firm's NP readiness rhythm to the market receptivity rhythm over several generations of new products.

\section{A typology of product markets based on rhythms}

As observed by authors such as Lambert and Slater (1999) and Morgan et al. (2001), the influence and importance of NP readiness and market rhythms vary as a function of product market factors. Lambert and Slater (1999) identify product markets where the windows for a new product launch are imposed (e.g., the pharmaceutical industry, where the rhythm is imposed by the duration of patent protection rights) and product markets where the windows for a new product launch is controllable by the firms (e.g., microprocessor or operating systems markets where Intel and Microsoft operate in fairly controllable market windows). Morgan et al. (2001) identify product markets where each generation of new products can be planned in relative isolation (e.g., commercial jets, refineries, etc.) and others where a technology can be extended through evolutionary advances in product or process technology and/or better customer understanding, so that a multiple product generation framework is more appropriate.

To classify these different product markets, we propose a $2 \times 2$ matrix typology based on the relative influence of NP readiness and market rhythms (see Figure 2). In some product markets, one of the rhythms may be the leader and instigate the other rhythm. We refer to the leader rhythm as being an active rhythm. The follower is referred to as a passive rhythm. In other product markets, neither rhythm may be a leader or follower, but both may exist simultaneously and affect each other with 


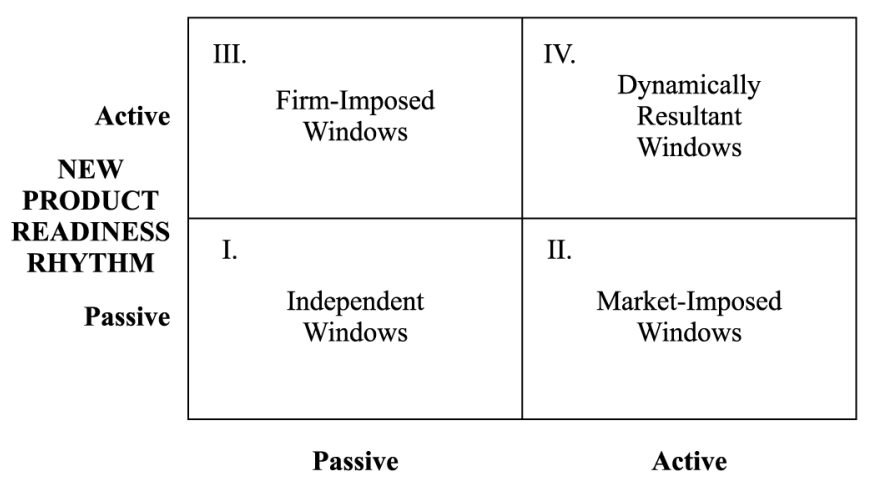

MARKET RHYTHM
Figure 2.

Typology of new product readiness and product market rhythm influences

similar intensity. In some of these product markets, both rhythms may be very active, while in other product markets, both rhythms may be quite passive. In this latter case, when both rhythms are passive, the implication is that each new product generation may be developed independently by a firm. In the other cases, the implications are more complex: when the market rhythm is active and the firm NP readiness is passive, the firm needs to adapt its NP readiness to the market rhythm; when the firm NP readiness rhythm is active and the market rhythm is passive, a firm needs to manage or control the market rhythm with pre-launch activities (including pre-announcements); and when both rhythms are active, a dynamic synchronization is needed for long-term performance. To manage best in each type, we need to understand the antecedents of the rhythms in each window. The antecedents are discussed in a later section.

\section{Cell passive-passive - independent window}

This type of window is also referred in the literature as the individual window (Morgan et al., 2001) or emergent market window (Lambert and Slater, 1999). This type of window is the dominant case in very new markets and in existing markets after a major discontinuity has occurred. Products such as commercial jets and oil refineries have such long lives that, even though they build on existing technology, each generation can be planned in relative isolation (Morgan et al., 2001). Usually an independent window will evolve toward other market windows with the next generation of products.

\section{Cell passive-active - market-imposed window}

In product markets with such windows, the market receptivity rhythm strongly influences firms' readiness rhythm. For firms operating within market-imposed windows, it is necessary to synchronize with the market receptivity rhythm. The desktop Intel-based personal computer market presented by Lambert and Slater (1999) is an example of a market that has evolved toward market-imposed windows for all the players. In this market, rhythm is determined by Intel and Microsoft. For the personal computer assemblers, new product launches are strongly influenced by innovations at Intel and Microsoft. The pacemaker market described by Christensen (1997a, p. 4) is also characterized by market-imposed windows as shown in the following quote: 
Although Medtronic introduced its first dual-chamber pacemaker during this period, it did not follow it with an improved dual chamber device for another eight years. Deyo [Medtronic's Product Development and Technology Director] explained, "We were working on next-generation dual chamber product during all of those eight years. The problem was that just as we'd get ready to announce a new product, a competitor would come out with something better. So we'd force the funnel open again to allow for this new input, re-scope the project, and try to leap ahead of the competitor. Then just as we'd get ready with the improved version, a competitor would come in ahead of us with an even better product, and so on".

\section{Cell active-passive - firm-imposed window}

This type of window is also referred in the literature as a controllable market window (Lambert and Slater, 1999) and a monopolist environment (Boone et al., 2001). The archetypal form of a firm-imposed window is a monopoly where there is a unique supplier that sets the standards for future products. Firms that operate within this type of window have nearly complete control over new product introduction timing (Lambert and Slater, 1999). In such windows, customers should anticipate next generation product release times and intergenerational improvement levels based on a firm's historical frequency and pattern of product introduction, and incorporate that information in their purchase decisions (Boone et al., 2001).

\section{Cell active-active -dynamically resultant window}

When both rhythms are active, we have product markets with dynamically resultant windows, where firms and customers try to mutually adjust their rhythms. Based on introduction frequency data from major introductions for Microsoft Windows, Intel microprocessors, and Microsoft Word for DOS and Windows, Lambert and Slater (1999) show that cycle times for significant products were either fairly flat or increasing. They conclude that instead of blindly pursuing speed, these companies dynamically synchronized their cycle times with customers' ability to assimilate new products and receptivity in terms of needs for periodic product improvements.

Based on the above discussion of the characteristics of the four different types of market windows, we make the following four propositions:

P1. In product markets characterized by independent windows, a firm's long-term performance is a function of its capacity to develop and launch new products based on disruptive or discontinuous innovations.

P2. In product market characterized by market-imposed windows, a firm's long-term performance is a function of its capacity to sense and adapt its new product launch rhythm to the market receptivity rhythm.

P3. In product markets characterized by firm-imposed windows, a firm's long-term performance is a function of its capacity to develop incremental innovation at a regular rhythm to pace market rhythm.

P4. In product market characterized by dynamically resultant windows, a firm's long-term performance is a function of its capacity to dynamically match its new product launch rhythm and the market rhythm.

To manage these windows, the antecedents of the rhythms have to be understood. 


\section{Antecedents of the rhythms}

Both, firm readiness rhythm and market receptivity rhythm are influenced by several factors. In this section, we present a set of propositions relating these rhythms to their antecedents.

\section{Antecedents of a firm's new product readiness rhythm}

We have defined readiness as the overall level of preparedness of the firm to introduce a new product and a firm's new product readiness rhythm as a firm relatively consistent cycle in developing and launching subsequent generations of its products. As illustrated in Figure 3, there are two characteristics of a firm that allow it to gain some control over its NP readiness rhythm: its dynamic capabilities (i.e. a firm's ability to launch multiple generations of new products) and its strategic intent (i.e. a firm's willingness to launch multiple generations of new products). A third element that can influence a firm NP readiness rhythm is market receptivity rhythm.

Dynamic capabilities. A firm's resources and capabilities place limits on its pace of technology advancement in specific new product development efforts as well as its

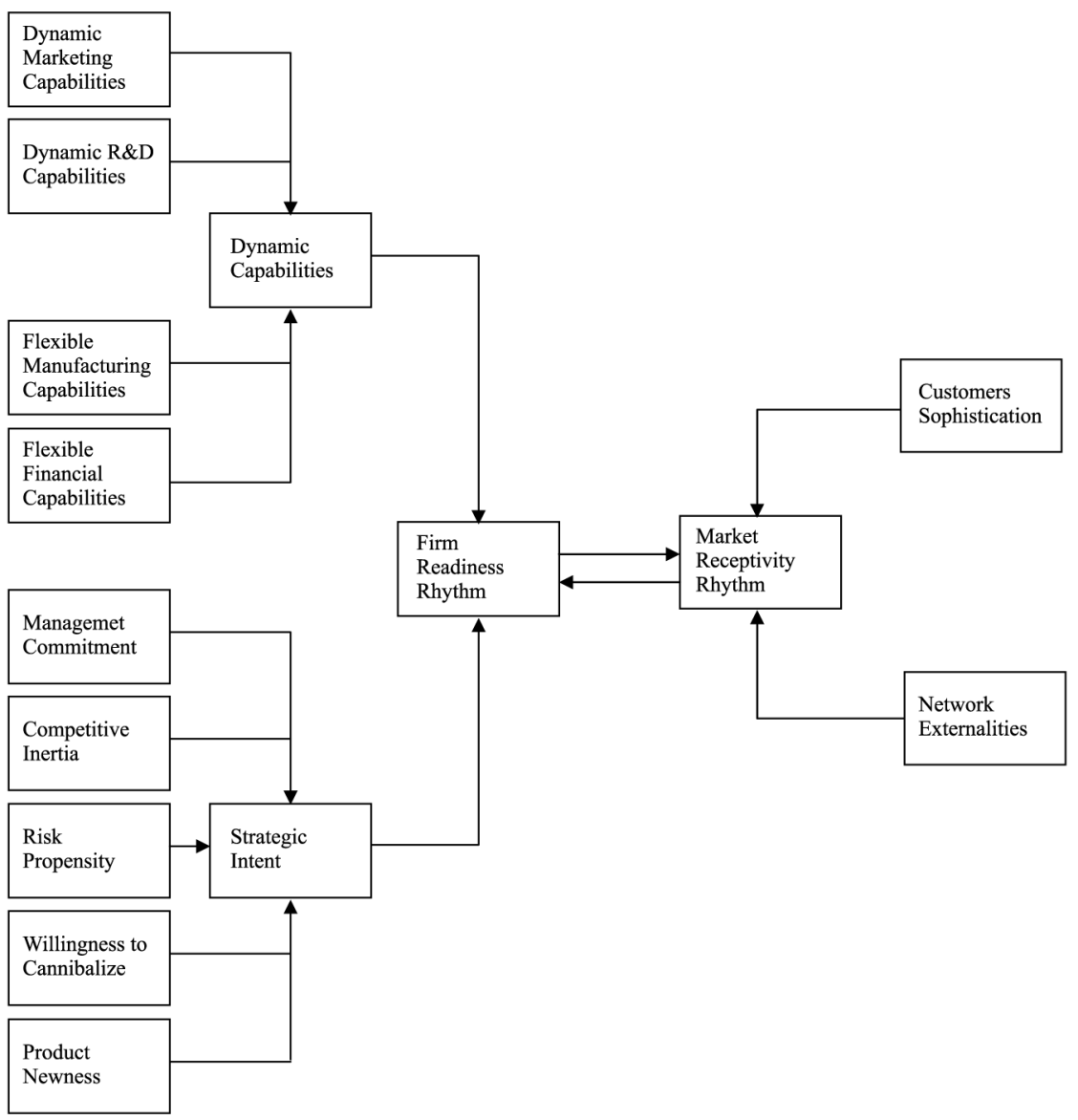

Figure 3.

Antecedents of firm readiness and market receptivity for technology-based new products 
ability to embrace new technologies. Semiconductor manufacturers, for example, need to make huge investments in plant and equipment that are not easily adaptable to next generation technologies. Therefore, in order to exploit new technologies, firms must have dynamic capabilities (Winter, 2002; Teece et al., 1997) to integrate, build, and reconfigure internal and external competencies to gain control over its NP readiness rhythm to match it with the market receptivity rhythm. In particular, abilities in the areas of marketing, research and development, manufacturing, and finance are key to a firm's readiness for exploiting current and new technologies (Stalk and Hout, 1990; Thomas, 1985). We now examine these four capabilities.

Dynamic marketing capabilities. Dynamic marketing capabilities (i.e. understanding of market rhythm and marketing flexibility) are important for a firm to control its NP readiness rhythm. Dickson's (1992) arguments toward a general theory of competitive rationality supports the view that successful firms are able to exploit successive market opportunities as a result of "acute, unbiased perceptions of change in the marketplace and the studious impact of such change on all facets of market decision making." Dynamic marketing capabilities in terms of understanding price-elasticity of demand relationships and key aspects of consumer behavior also help a firm to control its NP readiness rhythm. According to Golder and Tellis (1998) as well as Marsh and Stock (2003), a firm's ability to establish an appropriate product price can have a significant influence on the success of a product introduction. They cite, for example, the ability of Texas Instruments to pursue an aggressive low price strategy with their calculators as leading to their exponential sales growth. A lack of dynamic marketing capabilities will result in a slower and less controllable NP readiness rhythm. The above research emphasizes the importance of a firm's dynamic marketing capabilities for successfully managing individual new product introductions. More importantly, however, is the firm's abilities to manage its rhythm of successive product introductions. Where the above research clearly also applies but does not explicitly emphasize the management of multiple product generations, such reasoning suggests that:

P5. All else being equal, there is a positive relationship between a firm's dynamic marketing capabilities and the degree of control it has over its new product readiness rhythm.

Dynamic research and development capabilities. A firm's dynamic capabilities in R\&D (i.e. its flexible and programmatic R\&D capabilities) influence its NP readiness rhythm. A firm's absorptive capacity (Watanabe and Kwintiana, 2003; Cohen and Levinthal, $1990,1994)$ can be considered as its ability to exploit new technological developments. Studies by Cohen and Levinthal $(1990,1994)$ show analytically that, in the long run, firms that have a high absorptive capacity tend to perform better in the marketplace than firms with a low absorptive capacity. Clearly, then, it is important for firms to manage their technology development capabilities over the long-term while at the same time developing competencies in marketing.

Thomas (1993) argues that the nature of a firm's technological expertise is an important factor in determining the firm's propensity to innovate in new product development. Specifically, the author argues that if the technological expertise in an organization is relatively focused, it will be difficult for the firm to adopt a new technology. More generally, Thomas argues that the flexibility of a firm's new product 
development resources can influence its propensity to innovate and readiness to adopt new technologies. The adoption of new technologies into a firm in turn allows it to make either process or product technological innovations, which in turn allows it to develop and introduce successive new product generations. Knowledge management research by Grover and Davenport (2001) further supports the view that, over the long-term, successful firms are ones that are able to manage better knowledge that is both explicit (i.e. easily codified) as well as tacit, which may potentially be more process-oriented. A firm's dynamic R\&D capabilities act to determine its readiness to exploit and advance new technologies over multiple generations of new products.

P6. All else being equal, there is a positive relationship between a firm's dynamic research and development capabilities and the degree of control it has over its new product readiness rhythm.

Flexible manufacturing capabilities. In his research on time-based competition, Stalk (1988) considers manufacturing competencies to be an important time-based advantage that can accrue to a firm. The author cites many companies in Japan as striving to shorten production runs down to a single unit in an effort to maximize manufacturing readiness. Stronger manufacturing competencies, in turn, provide the firm with greater flexibility to exploit and advance new technologies incorporated into the firm's new products. In addition, slack resources (March and Simon, 1958) in manufacturing may also improve a firm's flexibility and readiness to introduce new products over multiple generations by enabling the firm to more easily accommodate the transitions from one generation of products to another. Reported by Emerson Process Management team (Rao, 2004), the ASEAN countries especially China, India and Taiwan have been gaining their competitive advantages in the global economy due to their manufacturing and designing competences. Among them, leading firms in Taiwan have continuously introducing multiple generations of new products in hightech industry such as IT industry. These results together with the reasoning above lead to the following proposition:

P7. All else being equal, there is a positive relationship between the flexibility of a firm's manufacturing capabilities and the degree of control it has over its new product readiness rhythm.

Flexible financial capabilities. A final area of a firm's dynamic capabilities is its financial capabilities. The importance of a firm's financial resources is examined and supported by empirical research by Karakaya and Stahl (1989) as well as by Stahl et al. (1997), p. 146) on market entry barriers. In a survey of executives, Karakaya and Stahl found that capital requirements are one of the most important market entry barriers facing firms in both consumer and industrial markets. Without appropriate capital, firms are severely limited in their ability to exploit and advance new technologies in the success generations of new products. For example, for industries such as pharmaceuticals or semiconductors that are highly capital-intensive, a firm's financial ability can drive or limit the firm's readiness to advance with new technologies:

P8. All else being equal, there is a positive relationship between the flexibility of a firm's financial capabilities and the degree of control it has over its new product readiness rhythm. 
In summing up, a firm's dynamic capabilities in marketing, R\&D, manufacturing, and finance are identified as important influences on the degree of control a firm has over its NP readiness rhythm. Such influences are likely to be highly complementary, where synergies result from strong capabilities and competences in each of these areas.

\section{Strategic intent}

Hamel and Prahalad $(1989,2005)$ argue that "in order to achieve success, a company must reconcile its end to its means through Strategic Intent" and define Strategic Intent as "ambitious and compelling ... dream that energizes ... that provides the emotional and intellectual energy for the journey ... to the future." In addition to the influence of a firm's capabilities and competencies, the literature also identifies strategic intent as a distinct and important influence on NP readiness rhythm. Unlike capabilities and competencies, which emphasize a firm's abilities to control its NP readiness rhythm, strategic intent emphasizes a firm's willingness or interest in exploiting and advancing new technologies in new products. Gatignon and Xuereb (1997) stress the influence of a firm's strategic orientation on its innovation performance. Key aspects of strategic intent include management commitment, competitive inertia, risk propensity, willingness to cannibalize, and product newness decision.

Management commitment. Management commitment is required for any initiative to be successful. Such a concept has been practiced in various institutions in private and public sectors including Tennessee Valley Authority's environmental protection initiatives in recent years. According to Quinn (1985, p. 77), "Continuous innovation occurs largely because top executives appreciate innovation and manage their company's value system and atmosphere to support it." In a study of new product development efforts of large, well-established firms, Dougherty and Corse (1996) found that management commitment is key if firms are to develop and maintain strong innovative capacities. Similarly, research by McDaniel and Kolari (1987) indicates that firms vary in their overall commitment to new product development, which in turn may affect their degree of control over their firm's NP readiness rhythm.

P9. All else being equal, there is a positive relationship between management commitment and a firm's degree of control over its new product readiness rhythm.

Competitive inertia. Competitive inertia refers to the level of activity that a firm demonstrates in altering its competitive stand (Miller and Chen, 1994). Leibold et al. (2005, p. 196) define it as "the focus on preserving an established competitive advantage, and on avoiding cannibalization of existing market shares and product". Introducing new products is one of the most important market-oriented changes a firm makes in trying to attract customers or out- maneuver competitors. Miller and Chen (1994) argue that competitive inertia is a product of managers' incentives to act, their awareness of action alternatives, and the constraints on their capacity to act. A firm with a high level of competitive inertia will likely have lesser control over its NP readiness rhythm relative to firms with less inertia. More formally:

P10. All else being equal, there is a negative relationship between competitive inertia and a firm's degree of control over its new product readiness rhythm. 
Risk propensity. Thomas (1985), in his conceptual research on market entry timing, notes that executive willingness to take risks is an important input to the process of new product development and market entry. The author considers that executive willingness to take risks can influence when the firm ultimately takes action in many areas. Supporting this view is research by Schnaars $(1986,1994)$ who notes that the basic strategy of some firms is to be a "follower," entering new products and/or markets only after some leader has clearly demonstrated that a viable market exists. Walsh (2002) found propensity to take risks has a significant impact on project success in new software development. Thus:

P11. All else being equal, there is a positive relationship between risk propensity and a firm's degree of control over its new product readiness rhythm.

Willingness to cannibalize. Another aspect of a firm's strategic intent is a firm's willingness to cannibalize its own products when introducing a new product. Willingness to cannibalize refers to the extent to which a firm is prepared to reduce the actual or potential value of its investments (Chandy and Tellis, 1998). Chandy and Tellis $(1998,2000)$ argue that one key variable that differentiates firms with strong radical product innovation records from others is the firms' willingness to cannibalize their own investments. Building on the work of Chandy and Tellis (1998), Nijssen et al. (2004) argue that a company's willingness to cannibalize on its sales is one key factor to understanding new service development. Research by Clarke (1993) supports this view as well, citing the example where General Food's reluctance to cannibalize its existing products with its introduction of Maxim freeze-dried coffee as having led to the competitive situation where both Maxim and its existing products were severely hurt:

P12. All else being equal, there is a positive relationship between willingness to cannibalize and a firm's degree of control over its new product readiness rhythm.

Product newness. Griffin (1997) empirically shows that product newness (the amount of product redesign from the previous product generation) has an impact on product development cycle time. Product newness is a matter of how much the product must be redesigned independent of the technological complexity and difficulty in making that change. Therefore, product newness is a strategic variable that influences a firm's readiness. The newer a firm chooses to make a new product, the more time the firm will need in order to be ready to launch it and the lesser control the firm will have over its NP readiness rhythm. Michaut (2004) also shows that product newness affects the market success of new product introductions.

P13. All else being equal, there is a negative relationship between the degree of product newness and a firm's degree of control over its new product readiness rhythm.

In summing up the research on a firm's attitudinal readiness to advance new technologies in their products, management commitment, competitive inertia, risk propensity, willingness to cannibalize, and selected product newness are identified as important influences. As with the influences on dynamic capabilities, these influences on attitudinal readiness are likely to be highly complementary, too, where a synergy results from a strong firm willingness and interest in each of these areas. Collectively, 
the literature suggests that both functional readiness and attitudinal readiness combine to influence a firm's readiness to exploit and advance new technologies in new products.

Influence of market receptivity rhythm. As mentioned earlier in the discussion of the different types of product market windows, an active market receptivity rhythm also influences a firm's NP rhythm. The more active or dominant the market's rhythm is, the more difficult it is for managers to control their NP rhythm.

P14. All else being equal, there is a negative relationship between the active-ness of market receptivity rhythm and a firm's degree of control over its new product readiness rhythm.

\section{Antecedents of market receptivity rhythm}

We have defined the market receptivity rhythm, or product market rhythm, as the regular recurrence of favorable marketplace receptivity for new-generation products. Just as the consecutive new product introductions of a firm can be characterized by a cycle time of particular duration (e.g., from short to long cycle time), a market's receptivity rhythm, too, can be characterized by a cycle time of varying duration. As such, the strong presence of any factor tending to reduce or shorten the cycle time of a market's receptivity rhythm can be viewed as having a negative relationship with a market receptivity rhythm's cycle time. Clearly, relatively short market receptivity rhythm cycle times pose greater challenges for firms operating in windows where market receptivity rhythms are active and thus a careful understanding of influential factors is needed. There are two main factors that influence market receptivity rhythm: customers' sophistication and network externalities. A third element that can potentially influence market receptivity is a firm's NP readiness rhythm (see Figure 3).

Customers' sophistication. Lynn and Heintz (1992) consider customers' sophistication in terms of product use and knowledge to be an important aspect that firms should take into account when seeking to introduce new products. Specifically, they argue that customers will vary in their present state and rate of technology adoption. Similarly, Scherer (1967) argues that the rate of a market's development depends on the receptiveness of customers to new products, among other factors, noting that it takes time to overcome consumers' resistance to change and to develop the market's full potential. Research by Mahajan and Muller (1996) further supports the view that adopters' expectations about the performance of a new generation will affect their decisions of when and if to adopt it. Customer learning, or how fast and easily customers can learn to use new technologies, influences their sophistication speed. Recently, Sudharshan et al. (2006) have modeled the relationship between customer sophistication and timing for technology advancement. They show that higher customer sophistication leads to faster technology advancement by the firms. They also show that leapfrogging of the innovator's strategy by followers is optimal only under limited time windows. Their results further demonstrate that the rhythms on the market side are dictated by customer sophistication rate (i.e. the fraction of customers who start gaining in sophistication) and sophistication speed (extent of technology change preferred per unit of time) parameters. On the firm side, science and technology development is both a R\&D race as well as an absorptive capacity race. Thus, the following proposition is posited: 
P15. All else being equal, there is a negative relationship between increases in sophistication demand change (as captured by both the rate of customer sophistication and speed of customer sophistication) and the cycle time of market receptivity.

Network externalities. At the market level, elements of social structure including the level and type of word-of-mouth communication in the market, which may also be called market buzz, can influence market receptivity to a new technology. Kalish and Lilien (1986), for example, show analytically that negative word-of-mouth communication regarding a new technology in a market can slow its acceptance by consumers. The momentum resulting from the speed at which word-of-mouth communication moves throughout customer networks in a market can have dramatic influences on a market's receptivity to new technologies. Many aspects of the market's technological system structure can also act to influence sophistication rate. The nature and extent of network externalities in the market, such as user and technological networks, can influence technology receptivity by the market (Farrell and Saloner, 1986). An example of a network externality influence is shown with the rate of adoption of the telephone, where the innovation became more useful the more users there were (Tirole, 1990, p. 405). Similarly, the use of e-mails and instant messenger are becoming more popular as more people are equipped with the required equipments. Chun and Hahn's (2007) study shows that local network size and strength have significant positive effect on online messenger services. Switching costs associated with replacing products incorporating old technologies with new products incorporating new technologies can also be an influence (Lambert and Slater, 1999), as observed in the personal computer market. Thus, in addition to the extent of customers' sophistication regarding a new product or technology, a greater presence of network externalities that supports the utility gained by consumers' in adopting successive product generations will speed further the acceptance of multiple product generations:

P16. All else being equal, there is a negative relationship between the extent of network externalities and the market receptivity rhythm's cycle time.

Firms' NP readiness rhythm. Firms' NP readiness rhythm may also influence market receptivity through at least three avenues, namely promotional effects (Wind and Mahajan, 1987), preannouncement signaling effects (Crawford and Benedetto, 2006; Eliashberg and Robertson, 1988), and frequency and/or pattern of new generation product introductions (Boone et al., 2001). A firm's NP readiness rhythm generates an opportunity to educate potential users about the benefits and trends associated with using the new product via promotional efforts including mass communication and personal contacts. For example, many technology companies (e.g., Sony, Microsoft) synchronize new product introductions to coincide with annual trade shows, where both an anticipative trade press and potential customers can be more easily approached as a result of the company's annual new product introductions and promotional efforts. New product preannouncements are also an important influence on market receptivity rhythm (Robertson et al., 1995). For example, Eliashberg and Robertson (1988) show that new product preannouncements are useful to begin building customer awareness and to encourage word-of-mouth advertising among potential customers. Perceptions of customers concerning the pattern of introductions 
of new technology-based products also play an important role (Boone et al., 2001). Based on an experimental study, Boone et al. (2001) found that a change in the frequency and/or pattern of new generation product introduction influences customers' perceptions of future product introductions and ultimately influence their purchase actions:

P17. All else being equal, there is a negative relationship between the active-ness of firms' product market readiness rhythm and a market receptivity rhythm's cycle time.

\section{Discussion}

We have developed Table II to summarize the management implications of our paper. This table distinguishes between the dynamic capabilities and the strategic intent that are both necessary for managing multiple generations of new products in the four types of windows we have identified earlier. Table II also summarizes how different marketing tools, such as preannouncements, promotional effects, and frequency/pattern of new product introductions, may be used to influence the market receptivity rhythm or adjust a firm's NP readiness rhythm to the market receptivity rhythm in the four types of windows.

In independent windows, the management focus is on a single generation and each successive generation can be planned independently. Therefore, in such windows, managers should develop dynamic capabilities geared to optimizing new product introductions for each generation independently. In terms of marketing, such capabilities are, for example, a strong ability to evaluate and manage short-term marketing objectives and marketing mix effectiveness. In terms of R\&D capabilities, new product development should be highly focused and emphasize product characteristics or production processes. In independent windows, the optimization of manufacturing resources leads firms to use relatively long production runs and minimal slacks to gain efficiency. Financial efficiency also requires keeping the use of capital and financial resources for new product development to a strict minimum. In such windows, we observe a weak management commitment to innovation, high competitive inertia, and high risk aversion. Because the performance of each single generation of new product should be maximized, managers are often strongly reluctant to cannibalize their own products and new product development investments. In such independent windows, innovations are more likely to be disruptive than incremental. Since NP readiness and market receptivity are both passive, firms have no interest in managing market receptivity, therefore preannouncements and promotional effects are typically not used.

In market-imposed windows, firms aim at adapting their own NP readiness rhythm to the market receptivity rhythm. To accomplish that effectively, they need to develop dynamic capabilities necessary to sense and to flexibly adapt themselves to the market rhythm. They need to develop strong abilities to assess long-term marketing effectiveness, and manage price-elasticity of demand. In market-imposed windows, firms need to develop the absorptive capacity to be able acquire and internalize external technologies. Flexible manufacturing and slack manufacturing resources are also required to allow firms to quickly switch to the next generation of new product when required by the market. To accomplish that, they need to have access to the appropriate capital and a strong willingness to use financial resources to follow the 


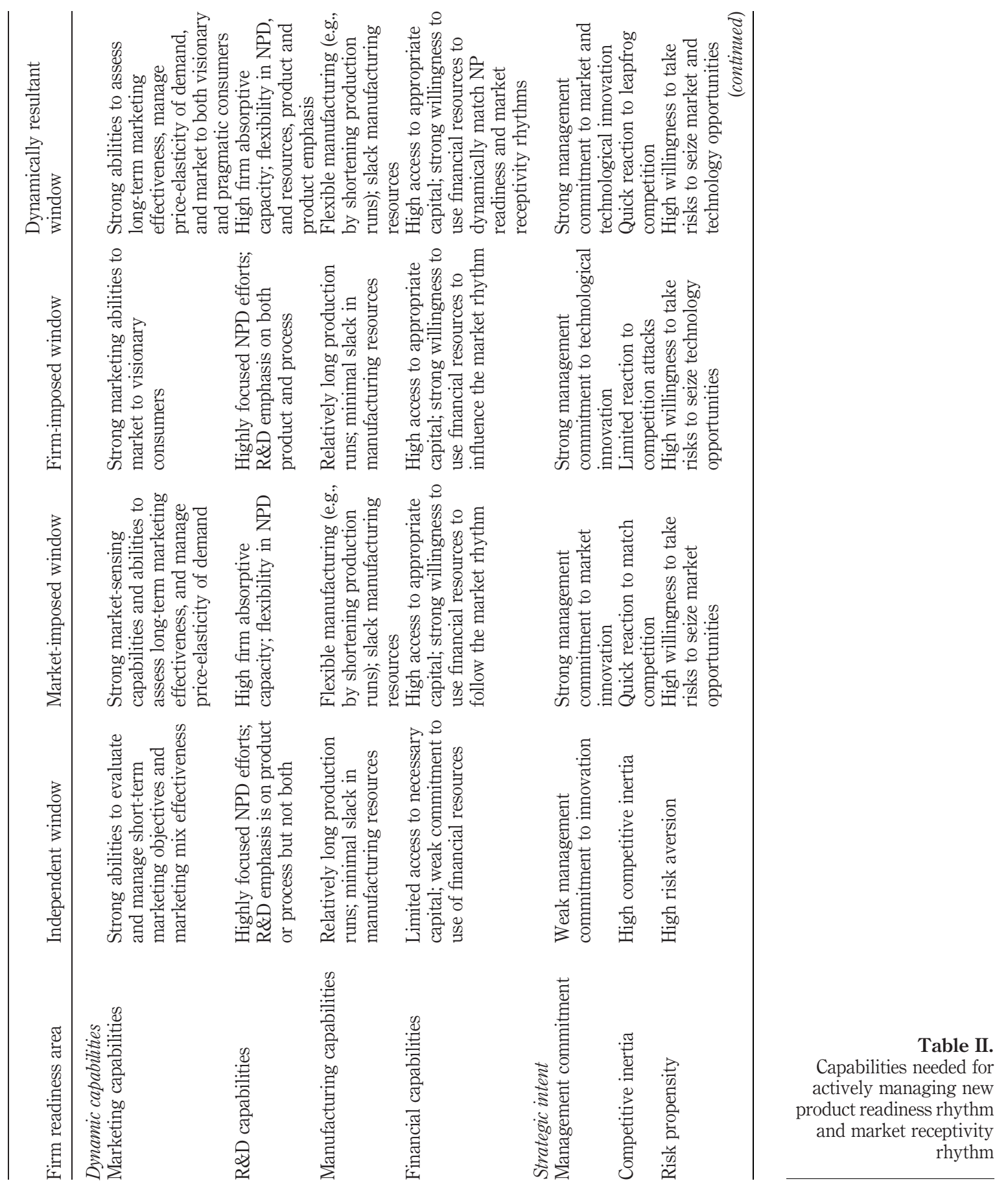




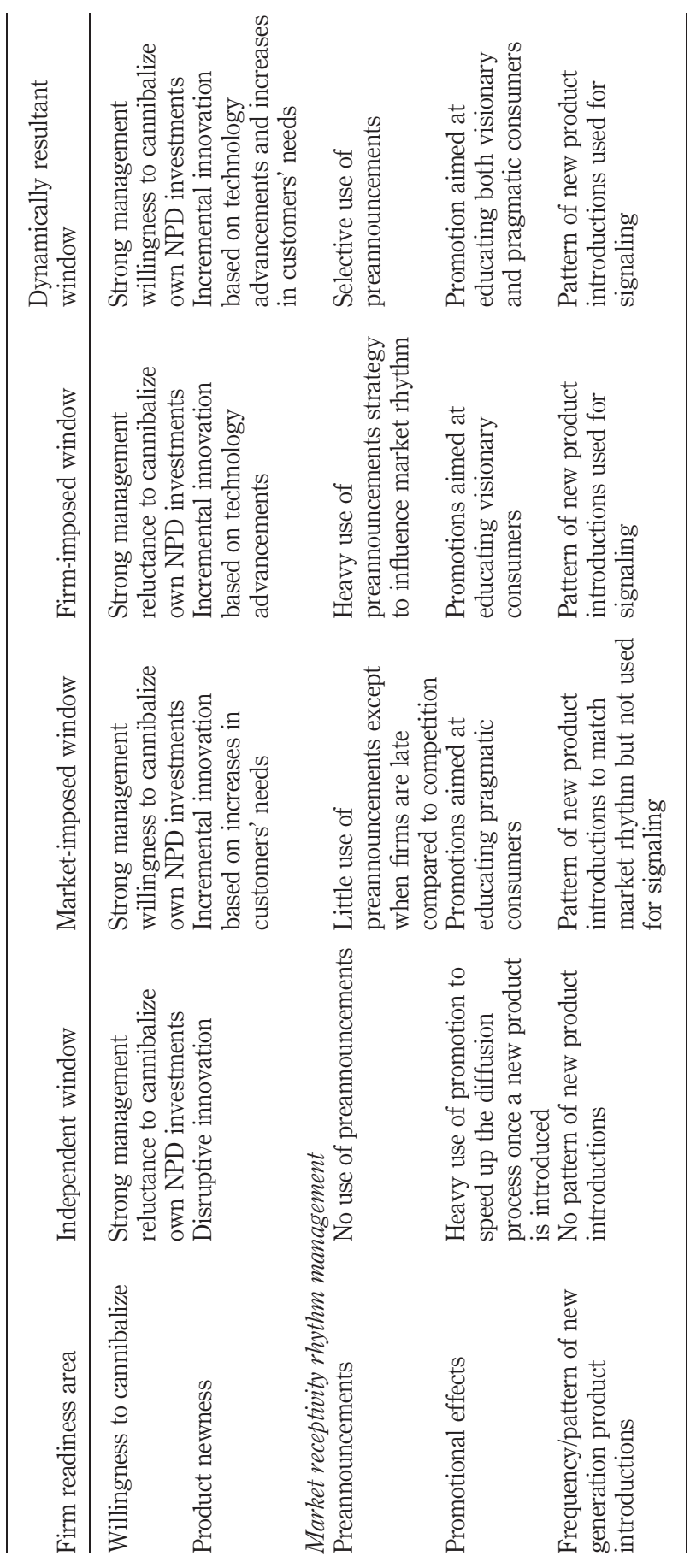


market rhythm. In market-imposed windows, management should be strongly committed to market innovation and be willing to quickly match moves from competitors. They should also be willing to take risks to seize market opportunities when they occur and to cannibalize their own new product development investments when necessary. The degree of product newness should be adapted to the evolution of customers' needs and innovation is incremental by nature. Since in market-imposed windows, the market receptivity rhythm is stronger, or more active, than firms' NP readiness rhythms, firms should not invest too much in trying to influence the market receptivity rhythm. Therefore, they should use preannouncements only when they are late compared to their competitors and promotion efforts should be aimed at educating pragmatic consumers rather than visionary ones. The pattern of new product introductions follows the market rhythm, therefore is not intended to signal future new product introduction times.

In firm-imposed windows, firms have the initiative to drive the market receptivity rhythm. In terms of marketing, they need the capabilities to identify the needs of visionary consumers and to market new products to them. They need to have very technologically focused new product development with an emphasis on both product characteristics and production processes. Being able to control their own NP readiness rhythm, firms in firm-imposed windows should optimize their manufacturing resources with relatively long production runs and minimal slacks. Financial resources are directed to gain economies of scale in production and in influencing the market readiness rhythm with preannouncements and promotional effects. In such windows, management should be strongly committed to technological innovation. Being able to control their NP readiness rhythm, firms do not necessarily need to commit to strong competitive responses, nor do they require a strong willingness to cannibalize their own products. However, management should be willing to take risks to seize technology opportunities and direct the attention to incremental innovation based on the advancement of technology. To drive the market receptivity, firms in such windows should heavily use marketing tools such as preannouncements and promotion strategy to influence and educate visionary consumers. Patterns of new product introductions may be used to signal the timing of the launch of the next generation of new products.

In dynamically resultant windows, everything is more complicated because firms' $\mathrm{NP}$ readiness rhythm and market receptivity rhythm influence each other. In such windows, firms should carefully manage their NP receptivity rhythm to match the market receptivity rhythm and at the same time they should work at influencing this market receptivity rhythm. In such a situation, firms need to possess the dynamic capability used by firms in market-imposed windows as well as those used by firms in firm-imposed windows. They need flexible marketing capabilities to sense the market and need to be able to market their new products to visionary as well as pragmatic consumers. They need to develop the necessary absorptive capacity, flexibility in new product development, and possess flexible manufacturing processes and slack manufacturing resources. Access to capital is extremely important for these firms to stay flexible in their process of dynamically matching their NP readiness rhythm with the market receptivity rhythm. Management should be strongly committed to market and technological innovation and should be able to react quickly to a competitive attack by leapfrogging competitor new products rather than matching their 
characteristics. Therefore, they must be willing to take risks to seize market and technology opportunities as well as to cannibalize their own new product development investments. The degree of product newness of next generation products should be based on technology advancements as well as increases in customers' needs. Marketing tools such as preannouncements and promotion effects should be only used selectively to avoid the problem of vaporware (Bayus et al., 2001) in such a dynamically synchronized environment.

In summary, we believe that our paper provides a rich conceptual framework drawing together extant research on the development and introduction of new products. The framework is intended both to explicitly inform managers of the importance of rhythm matching as well as to the factors that influence such matching. It is also intended to provide a lens with which further research can be directed to increase the efficiency and effectiveness of resource utilization in new product development and the long-term success of the firms.

\section{Future research}

The primary emphasis of the research of this study is to conceptualize the relationship between firm readiness rhythm and market receptivity rhythm and the antecedents of each as well as to propose both a typology of new product readiness rhythm/market readiness rhythm windows and subsequent prescriptions for managerial action. Future research, therefore, will necessarily focus on the measurement and testing issues associated with these conceptualizations, propositions, and managerial prescriptions. In this regard, an immediately apparent benefit of the research of this study is the identification of relevant prior research which provides accepted means with which to operationalize with relative ease many of the constructs discussed. For example, the research by Karakaya and Stahl (1989) on financial capabilities, Gatignon and Xuereb (1997) on strategic intent, Walsh (2002) on risk propensity, and Griffin (1997) on product newness, provide detailed guidance on the means with which to immediately operationalize these respective constructs in support of evaluating a number of the propositions presented in this study. In this regard, near-term future research may emphasize data collection and analyses within firms across multiple industries using such accepted operationalizations. At the same time, it can also be said that most all of the other constructs discussed in this study are amenable to operationalizations involving scales created from relatively small numbers of survey-based questions administered to managerial respondents within firms. It is therefore considered to be feasible - and desirable - that the relationships and propositions put forth in this study should be tested via quantitative survey-based methodologies involving managerial respondents across a range of industries and markets which are likely to include characteristics of each of the four new product readiness rhythm/market readiness windows proposed and discussed in this study. Once such studies are conducted, subsequent research can focus on the development of models, ideally involving data collected across multiple product-markets, evaluating and assessing the relative importance and contribution of the different factors identified in this study to a range of product-markets of interest (e.g., markets for technology-based products).

There are, of course, certain issues or challenges associated with the above efforts that future researchers in this area will need to address. From a modeling perspective, 
researchers in this area will need to establish appropriate time lags (e.g., one or more multiples of months, quarters, or years) which most accurately capture the realities associated with the different relationships proposed in this research, either specifically or collectively (e.g., the influence of a firm's new product readiness rhythm on market receptivity). To be sure, the current state of marketing modeling knowledge of relevant time series analysis methods and techniques, which has seen numerous advances relatively recently, is now considered wholly adequate for enabling the marketing researcher to conduct such analyses and arrive at sound conclusions even though it is also recognized that exciting research opportunities in this area continue to be present (Pauwels et al., 2004). Beyond these areas for near-term future research, given the managerial prescriptions presented in this study, longer term research will then need to necessarily focus on accurately capturing the extent that new or revised managerial actions in one or more areas, for example, a firm's intentionally increased willingness to cannibalize, have a measurable impact - again, given appropriate time lags, on multiple measures of the firm's performance (e.g., sales, profitability, and market share). At the same time, it should also be noted that future research aimed at capturing management perceptions and expectations in each of the above areas may be of equally high value as that of objective quantitative assessments given that marketing decisions in a great many firms are made without the benefit of such rigorous assessments. Such findings may also be useful for subsequent theorizing on the nature of managerial biases and tendencies associated with marketing management and strategies involving multiple generations of products.

Finally, one important question raised by our research from a managerial implementation perspective is how a firm's measurement and decision support systems can be developed to more completely and permanently incorporate the proposed new product framework in order to achieve superior long-term performance. To the extent such systems are developed and implemented, it is argued that benefits will accrue for enhanced firm performance. Beyond this managerial benefit, a final benefit is that further opportunities are provided to validate and extend the propositions of our research.

\section{References}

Abell, D.F. (1978), "Strategic windows”, Journal of Marketing, Vol. 42, July, pp. 21-6.

Arslan, H., Kachani, S. and Shmatov, K. (2007), "Joint memory-dependent pricing and product introduction for multiple generations", 7th Annual INFORMS Pricing and Revenue Management Conference Proceedings, Barcelona, Spain.

Bass, F.M. (1969), “A new-product growth model for consumer durables”, Management Science, Vol. 15 No. 1, pp. 215-27.

Bayus, B.L. (1997), "Speed-to-market and new product performance trade-offs", Journal of Product Innovation Management, Vol. 14 No. 6, pp. 485-97.

Bayus, B.L., Jain, S. and Rao, A. (1997), "Too little and too early: introduction timing and new product performance in the personal digital assistant industry", Journal of Marketing Research, Vol. 34, February, pp. 50-63.

Bayus, B.L., Jain, S. and Rao, A. (2001), "Truth or consequences: an analysis of Vaporware and new product announcements", Journal of Marketing Research, Vol. 38, February, pp. 3-13. 
Boone, D.S., Lemon, K.N. and Staelin, R. (2001), "The impact of firm introductory strategies on consumers' perceptions of future product introductions and purchase decisions", Journal of Product Innovation Management, Vol. 18 No. 2, pp. 96-109.

Brooks, F.P. (1975), The Mythical Man-month: Essays on Software Engineering, Addison-Wesley, Reading, MA.

Brown, S.L. and Eisenhardt, K.M. (1998), Competing on the Edge: Strategy as Structured Chaos, Harvard Business School Press, Boston, MA.

Carpenter, G.S. and Nakamoto, K. (1989), "Consumer preference formation and pioneering advantage”, Journal of Marketing Research, Vol. 26, August, pp. 285-98.

Chandy, R.K. and Tellis, G.J. (1998), "Organizing for radical product innovation: the overlooked role of willingness to cannibalize”, Journal of Marketing Research, Vol. 35 No. 4, pp. 474-87.

Chandy, R.K. and Tellis, G.J. (2000), "The incumbent's curse? incumbency, size, and radical product innovation", Journal of Marketing, Vol. 64 No. 3, pp. 1-17.

Christensen, C.M. (1997a), We've Got Rhythm! Medtronic Corporation's Cardiac Pacemaker Business, HBS Case 9-698-004, Harvard Business School Publishing, Boston, MA.

Christensen, C.M. (1997b), The Innovator's Dilemma: When New Technologies Cause Great Firms to Fail, Harvard Business School Press, Boston, MA.

Chun, S.Y. and Hahn, M. (2007), "Network externality and future usage of internet services", Internet Research: Electronic Networking Applications and Policy, Vol. 17 No. 2, pp. 156-68.

Clarke, D.G. (1993), Marketing Analysis and Decision Making, Scientific Press, San Francisco, CA.

Cohen, M.A., Eliashberg, J. and Ho, T.H. (1996), "New product development: the performance and time-to-market tradeoff”, Management Science, Vol. 42 No. 2, pp. 173-86.

Cohen, W.M. and Levinthal, D.A. (1990), "Absorptive capacity: a new perspective on learning and innovation”, Administrative Science Quarterly, Vol. 35 No. 1, pp. 128-52.

Cohen, W.M. and Levinthal, D.A. (1994), "Fortune favors the prepared firm", Management Science, Vol. 40, February, pp. 227-51.

Conte, M., Santoro, R., Riedel, J.H. and Pawar, K.S. (2004), “The Aricon VE readiness assessment approach in the new product development (NPD) context", Virtual Enterprises and Collaborative Networks, No. 149, pp. 499-506.

Cooper, R.G. and Kleinschmidt, E.J. (1987), "New products: what separates winners from losers?”, Journal of Product Innovation and Management, Vol. 4 No. 2, pp. 169-84.

Cooper, R.G. and Kleinschmidt, E.J. (1994), "Determinants of timeliness in product development”, Journal of Product Innovation and Management, Vol. 11 No. 5, pp. 381-96.

Crawford, C.M. (1992), "The hidden costs of accelerated product development", Journal of Product Innovation and Management, Vol. 9 No. 2, pp. 188-99.

Crawford, C.M. and Benedetto, A.D. (2006), New Product Management, 8th ed., McGraw-Hill/Irwin, New York, NY, Chs. 16-18.

Dickson, P.R. (1992), "Toward a general theory of competitive rationality”, Journal of Marketing, Vol. 56 No. 1, pp. 69-83.

Dougherty, D. and Corse, S. (1996), What Does It Take to Take Advantage of Product Innovation?, Report Summary No. 96-109, Marketing Science Institute, Cambridge, MA.

Edelheit, L.S. (2004), "Perspective on GE research and development", Research-Technology Management, January 1, pp. 1-17.

Eisenhardt, K.M. and Brown, S.L. (1998), “Time pacing: competing in markets that won't stand still”, Harvard Business Review, Vol. 76, March-April, pp. 59-69. 
Eliashberg, J. and Robertson, T.S. (1988), "New product preannouncing behavior: a market signaling study", Journal of Marketing Research, Vol. 25, August, pp. 282-92.

Farrell, J. and Saloner, G. (1986), "Installed base and compatibility: innovation, product preannouncements, and prediction”, American Economic Review, Vol. 76, December, pp. $940-55$.

Foster, R.N. (1982), "Boosting the payoff from R\&D”, Research Management, January, pp. 22-7.

Foster, R.N. (1986), Innovation: The Attacker's Advantage, Summit Books, New York, NY.

Gatignon, H. and Xuereb, J.M. (1997), "Strategic orientation of the firm and new product performance", Journal of Marketing Research, Vol. 34 No. 1, pp. 77-90.

Gaynor, G.H. (1993), Exploiting Cycle Time in Technology Management, McGraw-Hill, New York, NY.

Gilbert, J.T. (1993), "Faster! newer! is not a strategy", SAM Advanced Management Journal, Vol. 58 No. 4, pp. 4-8.

Golder, P. and Tellis, G. (1998), "Beyond diffusion: an affordability model of the growth of new consumer durables", Journal of Forecasting, Vol. 17 No. 2, pp. 259-80.

Graves, S.B. (1989), "The time-cost tradeoff in research and development: a review", Engineering Costs and Production Economics, Vol. 16 No. 1, pp. 1-9.

Griffin, A. (1993), "Metrics for measuring product development cycle time", Journal of Product Innovation Management, Vol. 10 No. 2, pp. 112-25.

Griffin, A. (1997), "The effect of project and process characteristics on product development cycle time", Journal of Marketing Research, Vol. 34, February, pp. 24-35.

Grover, V. and Davenport, T.H. (2001), "General perspectives on knowledge management: fostering a research agenda”, Journal of Management Information Systems, Vol. 18 No. 1, pp. 5-21.

Hamel, G. and Prahalad, C.K. (1989), "Strategic intent", Harvard Business Review, Vol. 67 No. 3, pp. 63-76.

Hamel, G. and Prahalad, C.K. (2005), "Strategic intent", Harvard Business Review Classic Reprint, PN: R0507N.

Hauser, J., Tellis, G.J. and Griffin, A. (2006), "Research on innovation: a review and agenda for marketing science”, Marketing Science, Vol. 25 No. 6, pp. 687-717.

Holmes, T.L. and Srivastava, R. (1999), "Effects of relationalism and readiness on EDI collaboration and outcomes", The Journal of Business \& Industrial Marketing, Vol. 14 Nos 5/6, pp. 390-402.

Kalish, S. and Lilien, G.L. (1986), "A market timing model for new technologies", Management Science, Vol. 32 No. 2, pp. 194-205.

Kalyanaram, G., Robinson, W.T. and Urban, G.L. (1995), "Order of market entry: established empirical generalizations, emerging empirical generalizations, and future research", Marketing Science, Vol. 14 No. 3, pp. 212-21.

Karakaya, F. and Stahl, M.J. (1989), "Barriers to entry and market entry decisions in consumer and industrial goods markets", Journal of Marketing, Vol. 53 No. 2, pp. 80-91.

Kerin, R.A., Varadarajan, P.R. and Peterson, R.A. (1992), "First-mover advantage: a synthesis, conceptual framework, and research propositions", Journal of Marketing, Vol. 56 No. 4, pp. 33-52.

Kim, N., Chang, D.R. and Shocker, A.D. (2000), "Modeling intercategory and generational dynamics for a growing information technology industry", Management Science, Vol. 46 No. 4, pp. 496-512. 
Krishman, V. (2001), "Sparking growth and renewal through new products", Texas Business Review, April, pp. 1-6.

Laitner, D. (1998), "Growth forum: identifying and exploring opportunities for strategic innovation”, Visions, Vol. 22 No. 3, pp. 7-11 (interviews with Kathleen Eisenhardt and Michael Tushman).

Lambert, D. and Slater, S.F. (1999), "First, fast, and on time: the path to success. Or is it?", Journal of Product Innovation Management, Vol. 16 No. 5, pp. 427-38.

Leibold, M., Probst, G.J.B. and Gibbert, M. (2005), Strategic Management in the Knowledge Economy: New Approaches and Business Applications, John Wiley, New York, NY.

Leonard-Barton, D. (1992), "Core capabilities and core rigidities: a paradox in managing new product development”, Strategic Management Journal, Vol. 13, SSI, pp. 111-25.

Lieberman, M.B. and Montgomery, D.B. (1988), "First-mover advantages", Strategic Management Journal, Vol. 9, SSI, pp. 41-58.

Lynn, F. and Heintz, S. (1992), "Where does your new technology fit into the marketplace?", Journal of Product Innovation and Management, Vol. 9 No. 1, pp. 19-25.

McDaniel, S.W. and Kolari, J.W. (1987), "Marketing strategy implications of the Miles and Snow strategic typology", Journal of Marketing, Vol. 51 No. 4, pp. 19-30.

Mahajan, V. and Muller, E. (1996), "Timing, diffusion, and substitution of successive generations of technological innovations: the IBM mainframe case", Technological Forecasting and Social Change, Vol. 51 No. 2, pp. 109-32.

Manton, S. and Tennant, C. (2000), "Product development performance", working paper, Warwick Manufacturing Group, University of Warwick, Coventry, February, pp. 1-15.

March, J.G. and Simon, H.A. (1958), Organizations, Wiley, New York, NY.

Marsh, S.J. and Stock, G.N. (2003), "Building dynamic capabilities in new product development through intertemporal integration", Journal of Product Innovation Management, Vol. 20 No. 2, pp. 136-48.

Michaut, A.M.K. (2004), “Consumer response to innovative products: with application to foods", research paper series, Wageningen University, Wageningen.

Miller, C.M., McIntyre, S. and Mantrala, M. (1993), “Toward formalizing fashion theory”, Journal of Marketing Research, Vol. 30, May, pp. 142-57.

Miller, D. and Chen, M.-J. (1994), "Sources and consequences of competitive inertia: a study of the US airline industry”, Administrative Science Quarterly, Vol. 39 No. 1, pp. 1-23.

Milson, M.R., Raj, S.P. and Wilemon, D. (1992), “A survey of major approaches for accelerating new product development", Journal of Product Innovation Management, Vol. 9 No. 1, pp. 53-69.

More, R.A. (1984), "Timing of market research in new industrial product situations", Journal of Marketing, Vol. 48, Fall, pp. 84-94.

Morgan, L.O., Morgan, R.M. and Moore, W.L. (2001), "Quality and time-to-market trade-offs when there are multiple product generations", working paper, University of Utah, Salt Lake City, UT.

Nelson, S.G. and Winter, R.R. (1982), An Evolutionary Theory of Economic Change, Harvard University Press, Cambridge, MA.

Nijssen, E.J., Hillebrand, B., Vermeulen, P.A.M. and Kemp, R. (2004), Understanding the Role of Willingness to Cannibalize in New Service Development, Research Report H200308, Nijmegen School of Management, University of Nijmegen, Nijmegen. 
Norton, J.A. and Bass, F.M. (1987), "A diffusion theory model of adoption and substitution for successive generations of high-technology products", Management Science, Vol. 33 No. 9, pp. 1069-86.

Patterson, M.L. (1993), Accelerating Innovation: Improving the Process of Product Development, Van Nostrand Reichhold, New York, NY.

Pauwels, K., Currim, I., Dekimpe, M.G., Ghysels, E., Hanssens, D.M., Mizik, N. and Naik, P. (2004), "Modeling marketing dynamics by time series econometrics", Marketing Letters, Vol. 15 No. 4, pp. 167-83.

Quinn, J.B. (1985), "Managing innovation: controlled chaos”, Harvard Business Review, Vol. 63, May-June, pp. 73-84.

Rao, S. (2004), The China Effect - Emerson Process Management's Game Changing Performance, Research Report, Frost \& Sullivan, San Antonio, TX.

Robertson, T.J., Eliashberg, J. and Rymon, T. (1995), "New product announcement signals and incumbent reactions", Journal of Marketing, Vol. 59 No. 3, pp. 1-15.

Scherer, F.M. (1966), "Time-cost tradeoffs in uncertain empirical research projects", Naval Research Logistic Quarterly, Vol. 13 No. 1, pp. 71-82.

Scherer, F.M. (1967), "Research and development resource allocation under rivalry", The Quarterly Journal of Economics, Vol. 81 No. 3, pp. 359-94.

Schnaars, S.P. (1986), "When entering growth markets, are pioneers better than poachers?", Business Horizons, March-April, pp. 27-36.

Schnaars, S.P. (1994), Managing Imitation Strategies: How Later Entrants Seize Markets from Pioneers, Free Press, New York, NY.

Shankar, V., Carpenter, G.S. and Krishnamurthi, L. (1999), "The advantages of entry in the growth stage of the product life cycle: an empirical analysis", Journal of Marketing Research, Vol. 36 No. 2, pp. 269-76.

Smith, P.G. and Reinertsen, D.G. (1998), Developing Products in Half the Time: New Rules, New Tools, John Wiley \& Sons, New York, NY.

Stahl, M., Stahl, J. and Grigsby, D.W. (1997), Strategic Management: Total Quality and Global Competition, Blackwell Publishing, Oxford.

Stalk, G. Jr (1988), "Time - the next source of competitive advantage", Harvard Business Review, Vol. 66 No. 4, pp. 41-51.

Stalk, G. Jr and Hout, T.M. (1990), Competing against Time: How Time-based Competition Is Reshaping Global Markets, Free Press, New York, NY.

Sudharshan, D., Liu, B.S. and Ratchford, B.T. (2006), "Optimal response to a next generation new product introduction: to imitate or to leapfrog?", Managerial and Decision Economics, Vol. 27 No. 1, pp. 41-62.

Teece, D.J., Pisano, G. and Shuen, A. (1997), "Dynamic capabilities and strategic management", Strategic Management Journal, Vol. 18 No. 7, pp. 509-33.

Thomas, R.J. (1985), “Timing - the key to market entry”, Journal of Consumer Marketing, Vol. 2 No. 3, pp. 77-87.

Thomas, R.J. (1993), New Product Development: Managing and Forecasting for Strategic Success, John Wiley \& Sons, New York, NY.

Tirole, J. (1990), The Theory of Industrial Organization, The MIT Press, Cambridge, MA.

Vahaniitty, J. (2003), "Key decisions in strategic new product development for small software product businesses”, 29th Euromicro Conference (EUROMICRO'03), p. 375. 
von Hipple, E., Thomke, S. and Sonnack, M. (1999), "Creating breakthroughs at 3M", Harvard Business Review, Vol. 77 No. 11, pp. 3-9.

Walsh, K.R. (2002), "The role of motivation and risk behaviour in software development success", Information Research, Vol. 7 No. 3, April, available at: http://informationr.net/ir/ 7-3/paper129.html.

Watanabe, C. and Kwintiana, B.A. (2003), "Coevolution of manufacturing and service industry functions”, Journal of Service Research, Vol. 3 No. 1, April-September, pp. 101-18.

Wheelwright, S.C. and Clark, K.B. (1992), Revolutionizing Product Development, The Free Press, New York, NY.

Wind, J. and Mahajan, V. (1987), “Marketing hype: a new perspective for new product research”, Journal of Product Innovation Management, Vol. 4 No. 1, pp. 43-9.

Winter, S.G. (2002), "Understanding dynamic capabilities", WP2002-05, Working Paper, Reginald H. Jones Center, The Wharton School, University of Pennsylvania, Philadelphia, PA.

Womack, J.P., Jones, D.T. and Roos, D. (1985), The Machine that Changed the World, Rawson Associates, New York, NY.

Wong, T.Y.-D. (2003), "Move over, first mover: a theoretical and empirical analysis of first-mover advantages in the internet economy", unpublished thesis, Department of Economics, Stanford University, Palo Alto, CA.

Zirger, B.J. and Maidique, M.A. (1990), "A model of new product development: an empirical test”, Management Science, Vol. 36 No. 7, pp. 867-83.

\section{Further reading}

Gomory, R.E. (1989), "From the ladder of science to the product development cycle", Harvard Business Review, Vol. 67, November-December, pp. 99-105.

Kanter, R.M., Kao, J. and Wiersema, F. (1997), Innovation: Breakthrough Thinking at 3M, DuPont, GE, Pfizer, and Rubbermaid, HarperCollins Publishers, New York, NY.

\section{About the authors}

Scott G. Dacko is Associate Professor of Marketing and Strategic Management at Warwick Business School, The University of Warwick, Coventry, UK. He holds a PhD in Business Administration from the University of Illinois at Urbana-Champaign. His research interests include the study of marketing knowledge development and dissemination, temporal influences in marketing strategy and consumer behavior, and skill development in marketing education.

Ben S. Liu is Professor of Marketing at the Lender School of Business, Quinnipiac University, Hamden, Connecticutt, USA. He holds a PhD from the State University of New York at Buffalo. He was Assistant Professor at University of Illinois, Urbana-Champaign 1991-1999 and Associate Professor of Marketing at Butler University 2000-2007. Ben is visiting Professor of Marketing to various MBA, EMBA programs in China, Denmark, Hong Kong, Singapore, and Taiwan. His major research interest is in the areas of service marketing, cross-cultural effects, negotiation behaviors of buyers and sellers, distribution channel member relationships, and positioning strategy in new product development. He is on the editorial board of the Journal of Service Research. Ben S. Liu is the corresponding author and can be contacted at: bsliu@quinnipiac.edu

D. Sudharshan is Dean of the Gatton College of Business and Economics, University of Kentucky, Lexington, Kentucky, USA. He holds a PhD from the University of Pittsburgh. His research is in the areas of marketing strategy, new product development, and corporate strategy and technology management. He has published in leading journals such as Marketing Science, 
Management Science, Journal of Marketing, Journal of Marketing Research, Strategic Management Journal, and European Journal of Operational Management. His paper (with Maria T. Alexandre and Olivier Furrer) titled, "A hierarchical framework of new product development: an example from biotechnology," won the most Outstanding Paper in the 2003 volume of the European Journal of Innovation Management, Vol. 6, No. 1, pp. 48-63. He has served on the editorial boards of the Journal of Marketing, Journal of the Academy of Marketing Science and the Journal of Market Focused Management. He has considerable international teaching experience and was an award-winning teacher at the University of Illinois at Urbana Champaign. Sudharshan has led the development and implementation of several exciting new academic program initiatives at the University of Kentucky.

Olivier Furrer is Associate Professor Strategic Management at the Nijmegen School of Management, Radboud University Nijmegen, Nijmegen, The Netherlands. He holds a $\mathrm{PhD}$ in Business Administration from the University of Neuchâtel (Switzerland). His research interests include the study of cross-cultural service marketing, response strategies in strategic alliance, and global corporate social responsibilities. He is on the editorial board of the Journal of Service Research and of Service Business. 